\title{
公益社団法人日本不動産学会 2014年度通常総会報告
}

\author{
開催日時 2014年 5 月24日（土） $13: 30 \sim 14: 24$ \\ 2 開催場所東京 日本大学経済学部 7 号館 2 階講堂 \\ 3 総正会員数 920 名 \\ 4 出席正会員数 497名（委任状による出席を含む) \\ 5 議事録署名人 北詰恵一氏および松田佳久氏 \\ 6 議決事項
}

第 1 号議案 2013年度貸借対照表 (案), 正味財産増減計算書 (案) およびこれらの附属明細書 (案) 等について

原案通り承認可決されました。詳細は, 当学会ホームページ (http://www.jares.or.jp/general/official_ announcement.html）をご覧ください

\section{第 2 号議案 2014年度・2015年度理事および監事の選任について}

理事には，下記20氏が選任されました。

$$
\text { 記 }
$$

浅見泰司, 植松 丘, 上原由起夫, 大佛俊泰, 唐渡広志, 久米良昭, 斎藤参郎, 齊藤広子, 清水英範, 中井検裕, 中川雅之, 中城康彦, 原科幸彦, 氷鉋揚四郎, 福井秀夫, 巻島一郎, 三井康壽, 三橋博巳, 山崎福寿, 吉田修平

監事には，下記 2 氏が選任されました。

$$
\text { 記 }
$$

建部 好治, 湯浅 富一

\section{7 報告事項}

「2013年度事業報告について」,「2014年度事業計画について」,「2014年度収支予算について」，各担当常務理事 より報告がなされました。報告の詳細については，上記ホームページをご覧ください。

\section{《第 3 回理事会報告》}

本総会終了後開催されました第 3 回理事会において，会長，副会長，常務理事が，下記の通り選任されました。 記

会長 三井康壽

副 会 長原科幸彦, 植松 丘

常務理事 浅見泰司, 久米良昭, 中井検裕, 水鉋揚四郎, 福井秀夫

また，各委員会については，下記の通り選任されました。

記

$\begin{array}{ll}\text { 業績賞選考委員長・田中啓一賞選考委員長 } & \text { 三井康壽会長 } \\ \text { 論文・著作賞選考委員長 } & \text { 原科幸彦副会長 } \\ \text { 総務委員長 } & \text { 植松 丘副会長 } \\ \text { 事業企画委員長 } & \text { 氷鉋揚四郎常務理事 } \\ \text { 学術委員長 } & \text { 浅見泰司常務理事 } \\ \text { 国際交流・広報委員長 } & \text { 中井検裕常務理事 } \\ \text { 出版編集委員長 } & \text { 福井秀夫常務理事 }\end{array}$

